\title{
Mathematics Curriculum Review In Junior Secondary School Level: Implementation of Web-Based CRMS
}

\author{
Iin Habibah Muttaqin, Fatimah Rahmawati, Maman Fathurrohman, Cecep Anwar \\ Hadi Firdos Santosa \\ Sultan Ageng Tirtayasa University, Jl. Raya Ciwaru No. 25, Cipare, Serang, Banten, Indonesia, (0254) 280330 \\ e-mail: mamanf@untirta.ac.id
}

\begin{abstract}
This study aims to analyze the Indonesia National Curriculum (Kurikulum 2013) of mathematics at junior secondary school level. The tool used is the Web-based Curriculum Review Mapping System (CRMS). The CRMS was developed to analyze the curriculum, as expected outcome, through teachers lesson plan. The method used in this research was descriptive with a qualitative approach. In this research, the research was the main instrument assisted with interview guide sheets and documentations. The object of this research is the national curriculum for mathematics at a junior high school with three mathematics teachers as respondents to be interviewed. Analysis of the data used in the study is a qualitative analysis with three stages: data reduction, exposure, and drawing conclusions and verification. Qualitative data analysis is carried out simultaneously with data collection process. The results of the study state that the CRMS is at easy to implement by the teachers of mathematics. They can review their mathematics lesson plan using this system. Furthermore, by this system teachers could create various lesson plans.
\end{abstract}

Keywords: National Curriculum, Mathematics Curriculum, Curriculum Review Mapping System (CRMS)

How to Cite: : Muttaqin, I.H., Rahmawati, F., Fathurrohman, M \& Santosa, C.A.H.F. (2020). Mathematics Curriculum Review in Junior Secondary School Level: Implementation of Web-Based CRMS. International Journal on Emerging Mathematics Education, 4(2), 95-104. http://dx.doi.org/10.12928/ijeme.v4i2.16711

\section{INTRODUCTION}

Education is all the efforts of adults in interaction with children to lead the development of physical and spiritual towards the manhood (Purwanto, 2014). Education can help humans in facing the rapid development of the times that occur due to progress in the field of science. There are so many things that must be considered for the success of an educational process, one which is by perfecting the curriculum that follows the times, the development of science and technology. The curriculum is very important because the curriculum is the heart of an education that will determine the type and quality of education. The curriculum serves as a guide in the implementation of school education activities for related parties, both directly and indirectly, such as teachers, principals, communities, parents, and curriculum is one of the factors that contribute to the development of students (Johar, Yusniarti \& Saminan,. 2018).

The curriculum exists to shape the future of a country where a great country is inseparable from the education system as well as the curriculum implemented in that country. In Indonesian, the current curriculum is the 2013 curriculum. The 2013 curriculum is based on the foundation of the 2004 curriculum and 2006 curriculum (Kristiyani, 2019). The 2006 curriculum, known as KTSP, was developed into the 2013 curriculum based on thinking about future challenges, community perceptions, 
development of knowledge and pedagogy, future competencies, and negative phenomena that emerge (Rizkianto \& Santosa, 2017). The curriculum should be a bridge to get to each educational unit that breaks down several subjects in school. One of the subjects in school is mathematics. Mathematics is a universal science that underlies the development of modern technology, have an important role in a variety of disciplines and promote the power of human thought. To create and develop the future technology, it is important to have a strong mathematical ability since early ages (Revina \& Leung, 2018). Then the mathematics that students will get at school will be very useful for students in the future. With that, mathematics lessons in schools must be designed as well as possible so that the material delivered from the teacher to students can be accepted by students as a whole, because a teacher can help students improve academically and emotionally by starting programs that cultivate how to make good decisions, understand fellow students, relax, and focus on learning (Alrajeh \& Shindel, 2020).

In a research by Wati \& Jailani (2016), the readiness of junior high school mathematics teachers in implementing the 2013 curriculum in terms of teacher readiness falls into the very poor category. Thus, to achieve the goals of mathematics learning, the teacher makes a lesson plan in preparation for the teacher to carry out mathematics learning activities later in the classroom. But often teachers feel the mismatch between the lesson plan that has been made with the teaching and learning process in the classroom and the lesson plan that has been made is considered monotonous. This is also supported research by Haqiqi (2019) which says that there are some obstacles in implementing the 2013 curriculum, especially in the selection of teaching materials and research Ramda (2017) where the suitability of the material in the book with the assessment standards in the 2013 curriculum is only $54.55 \%$. Therefore, teachers need to review the lesson plans that have been made. Studying in the traditional or old-fashioned way is sure to be quite time-consuming and very inefficient. Teachers need a tool that can help in reviewing curriculum and mathematics learning plans, so that later mathematics teachers will no longer use traditional or old methods that will take time in the process.

The Curriculum Review Mapping System (CRMS) is a curriculum review system and a mathematics lesson plan that will help teachers in studying the curriculum and learning mathematics. CRMS is a development of curriculum assessment system and learning plans called excel-based LDMaps which are then developed into websitebased, so that teachers can use them wherever and whenever. LDMaps focuses on the process of analyzing curriculum and mathematics lesson plans, the results of which will be grouped into five types of information: subject information, learning resources, topics taught as classified with the mathematics subjects classification, distribution of graduate qualities, and Evaluation (Fathurrohman, Porter, Worthy, Abdullah , Supriyanto, Pamungkas., 2019). The CRMS will also focus on the process of analyzing the mathematics curriculum, the results of which will also be grouped into five types of information: designers, mathematics subject classification (MSC), resources, tasks, and supports. By using CRMS teachers are expected to no longer find it difficult to analyze curriculum and mathematics lesson plans.

\section{RESEARCH METHOD}

This research uses descriptive analysis method with a qualitative approach. According to Suprapto (2013) descriptive research is a study of the status, attitudes,

IJEME, Vol. 4, No. 2, September 2020, 95-104. 
opinions of individual groups, sets of conditions and procedures, a system of thought or event in order to make a description or picture systematically and analytically that can be used to solve an actual problem at the present time. Research with a qualitative approach is research that seeks to analyze social life by describing the social world from the point of view or interpretation of individuals (informants) in a natural setting. In other words qualitative research seeks to understand how does an individual see, understands or describes the social world (Sudaryono, 2017).

This research will be carried out in three stages: namely the research preparation stage, the implementation stage, and the report preparation stage. The preparation phase starts from determining the school, research permission at the school, and making interview instruments; the implementation phase begins by documenting the curriculum and junior high school mathematics lesson plan and then analyzed using a CRMS. Furthermore, researchers will conduct interviews with respondents; and the final stage is the stage of preparing a report that is compiling the results of research, discussing, and giving conclusions and suggestions from research results.

The object of research is the curriculum and mathematics lesson plan for junior high schools, while the respondents are three junior high school mathematics teachers consisting of mathematics teachers in grades VII, VIII, and IX. The three teachers were interviewed and asked for opinions to obtain in-depth information. The instruments used in this study were non-test instruments namely interviews, documentation, and the researchers themselves who became the main instrument.

Miles Huberman (Gunawan, 2015) suggests three stages that must be done in analyzing data with a qualitative approach, namely (1) data reduction; (2) data exposure; (3) drawing conclusions and verification. Qualitative data analysis is carried out simultaneously with the data collection process taking place. Reducing data is an activity to summarize, choose main points, focus on important things, and look for themes and patterns (Sugiyono, 2017). Reduced data will provide a clearer picture and make it easier to do data collection. Presentation of data is used to further enhance understanding of cases and as a reference for taking action based on understanding and analysis of data presentations. Withdrawal of conclusions is the result of research that answers the focus of research based on data analysis. Conclusions are presented in the form of descriptive research objects based on research studies (Gunawan, 2015).

\section{RESULTS AND DISCUSSION}

After getting the results of curriculum documentation and junior high school mathematics lesson plan, the curriculum and mathematics lesson plan are then analyzed using the Curriculum Review Mapping System (CRMS). Mathematics teachers can access the CRMS at the website address http://www.untirtasoftware.com/crms/pages/index.php. CRMS helps mathematics teachers in analyzing curriculum and lesson plans so that it does not take long enough in the process so that the time will be more effective and efficient. The use of CRMS that is easy to use by mathematics teachers can make it easier for junior high school mathematics teachers to analyze the curriculum and the lesson plans they arrange.

In the process of analyzing curriculum and mathematics learning plans with CRMS in the early stages the mathematics teacher will create a Generate LDMap File where there are Title which is the title of the LDMap File that you want to create; 
LDDate can be filled in the date of creation of the LDMap File that is being created; LDDisegner is an identity in the form of the name of the maker of the LDMap File; and Total Session contains the total sessions or meetings in each Title, for example the title material Linear Equation Two Variables in the learning implementation plan on the material there are four meetings then written on the Generate LDMap File Total Session section is four sessions that are tailored to the meeting on the lesson plan.

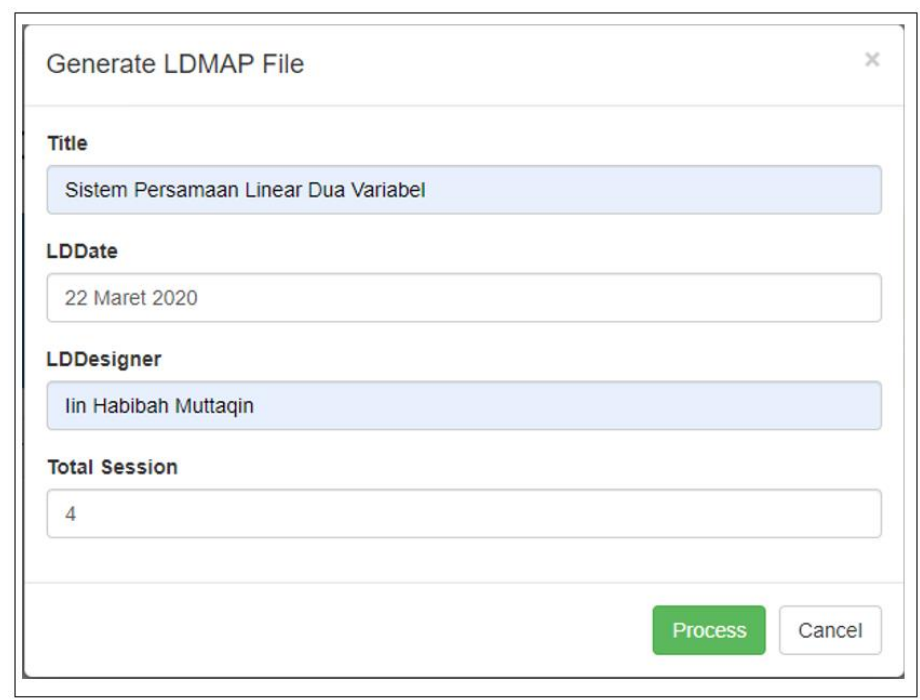

Figure 1. Generate LDMap File Material for Two Variable Linear Equation Systems

Generate XML LDMap File, after finishing with Generate LDMap File, the next step is to fill Generate XML LDMap File, there are some of these that must be filled in like Number of Session, Duration, DIntroduction, DMain, DComplation, RMain, RSupporting, RAdditional, TMain, Tsupporting, Additional, SMain, SSupport, SAdditional, Others, and Mathematics Subject Classification (MSC).

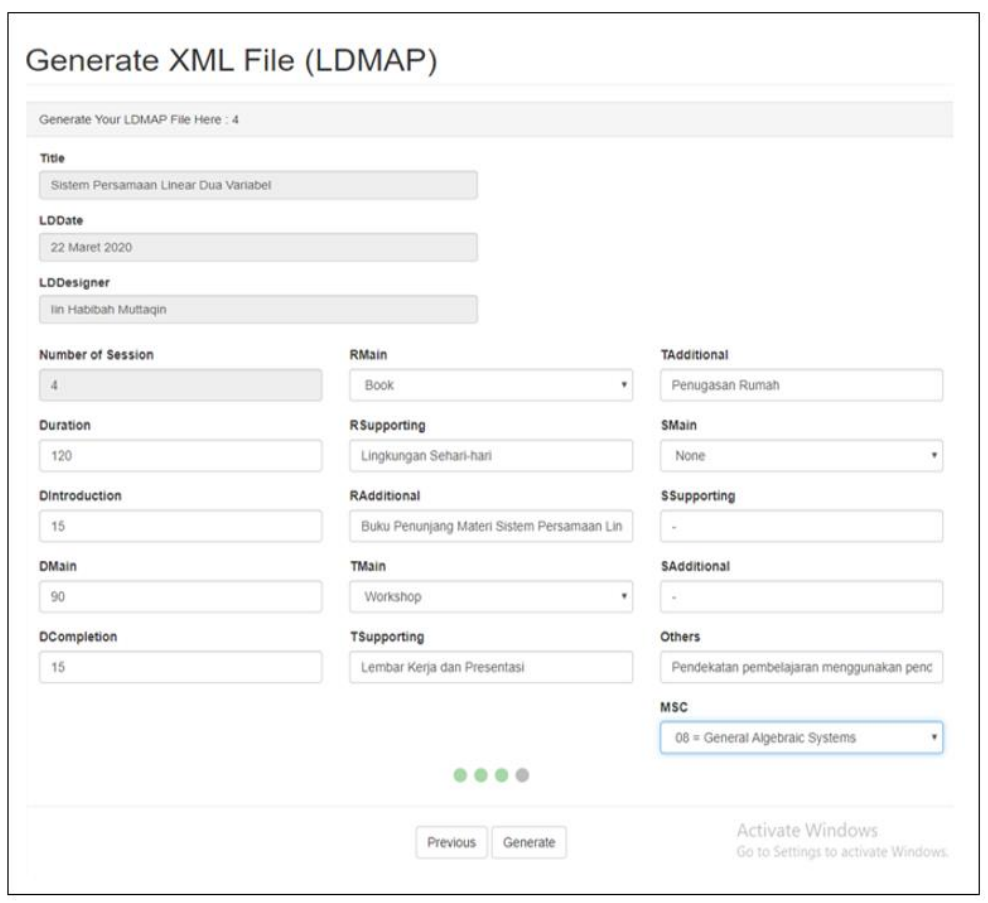

IJEME, Vol. 4, No. 2, September 2020, 95-104. 
Figure 2. Generate XML File LDMap Material Linear Equation System for Two Variables

After creating an XML Generate File LDMap there will be an XML file that will be downloaded automatically. The teacher can directly import the XML data file to find out the results of the curriculum study and the mathematics lesson plan that has been prepared.

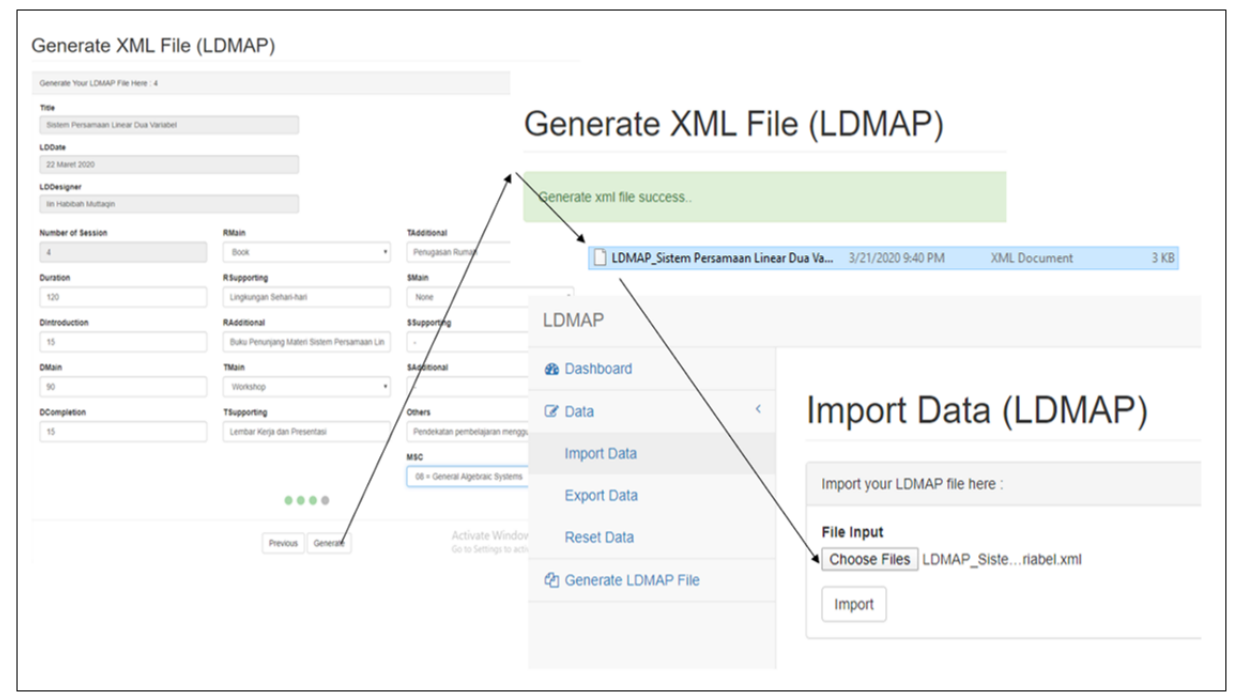

Figure 3. Import Data XML File LDMap Material for Two Variable Linear Equation Systems

After the mathematics teacher imports the data, the results of the curriculum review and lesson plan will be seen on dashboard of the CRMS account. To see the results of reviewing the lesson plan for one semester or one learning year, do the same steps for each mathematics material for one semester or one learning year. Besides importing, CRMS can also export and reset XML LDMap data files that have been created.

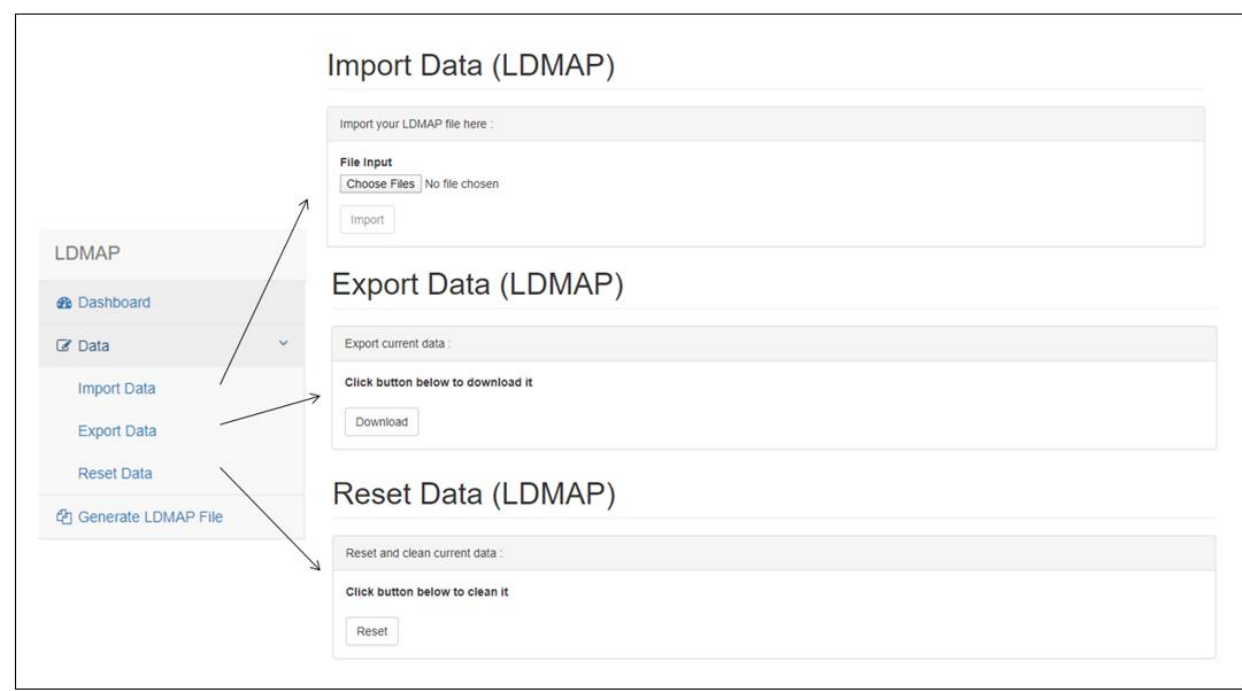

Figure 4. Import, Export, and Reset Data Curriculum Review Mapping System (CRMS) 
The import process is carried out to upload an XML File LDMap that has been previously created to view the results of the mathematics curriculum analysis on hhe dashboard. The teacher can upload multiple XML File LDMap to the import data if the XML File LDMap is created separately and want to see the results of curriculum analysis on one page. The teacher can also put together several XML File LDMap files that have been uploaded on the data import page and then put together by downloading files on the export data page, then the XML LDMap files that have been put together will be downloaded. If you want to delete the uploaded XML File LDMap data, then select reset on the reset data page so that the XML File LDMap will be deleted.

The results of curriculum analysis and mathematics lesson plans will be presented in the form of bar charts and percentage results that will be grouped into five types of information: designers, mathematics subject classification (MSC), resources, tasks, and supports.

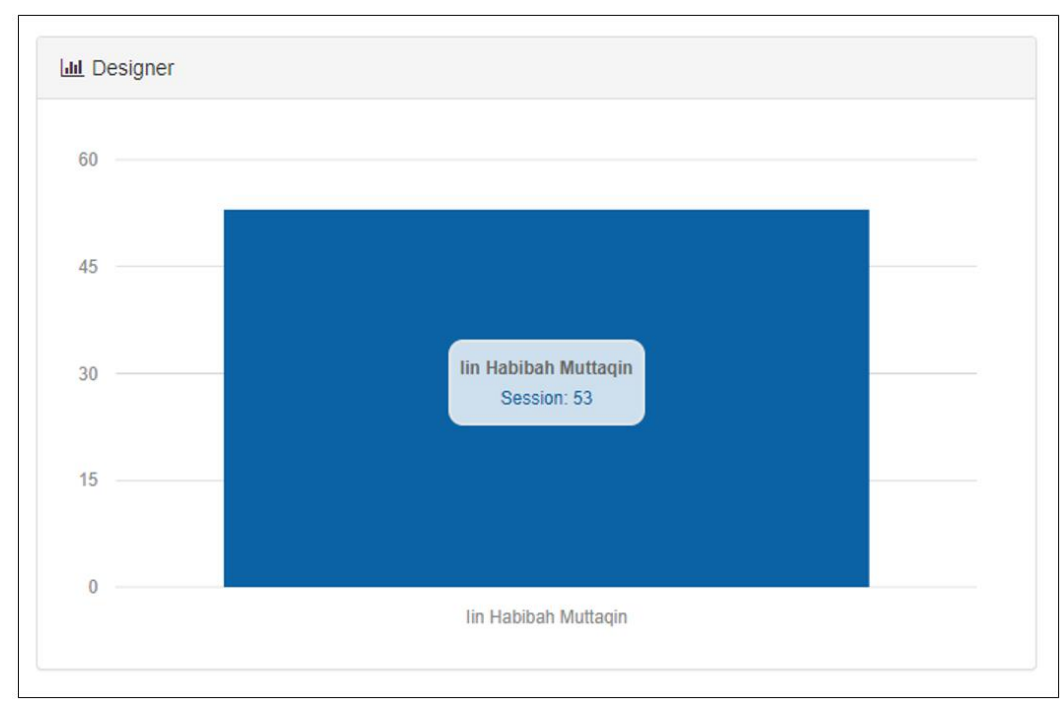

Figure 5. Results of Curriculum Analysis and Mathematics Lesson Plan Designer for Class VIII of Junior High School

The designer on the results of the curriculum analysis and lesson plan functions to find out who has made the XML File LDMap and review the mathematics lesson plan. There are a number of sessions in the curriculum analysis Designer and a mathematics lesson plan which means that the name listed has created 53 XML File LDMap or 53 meetings in one learning year. 


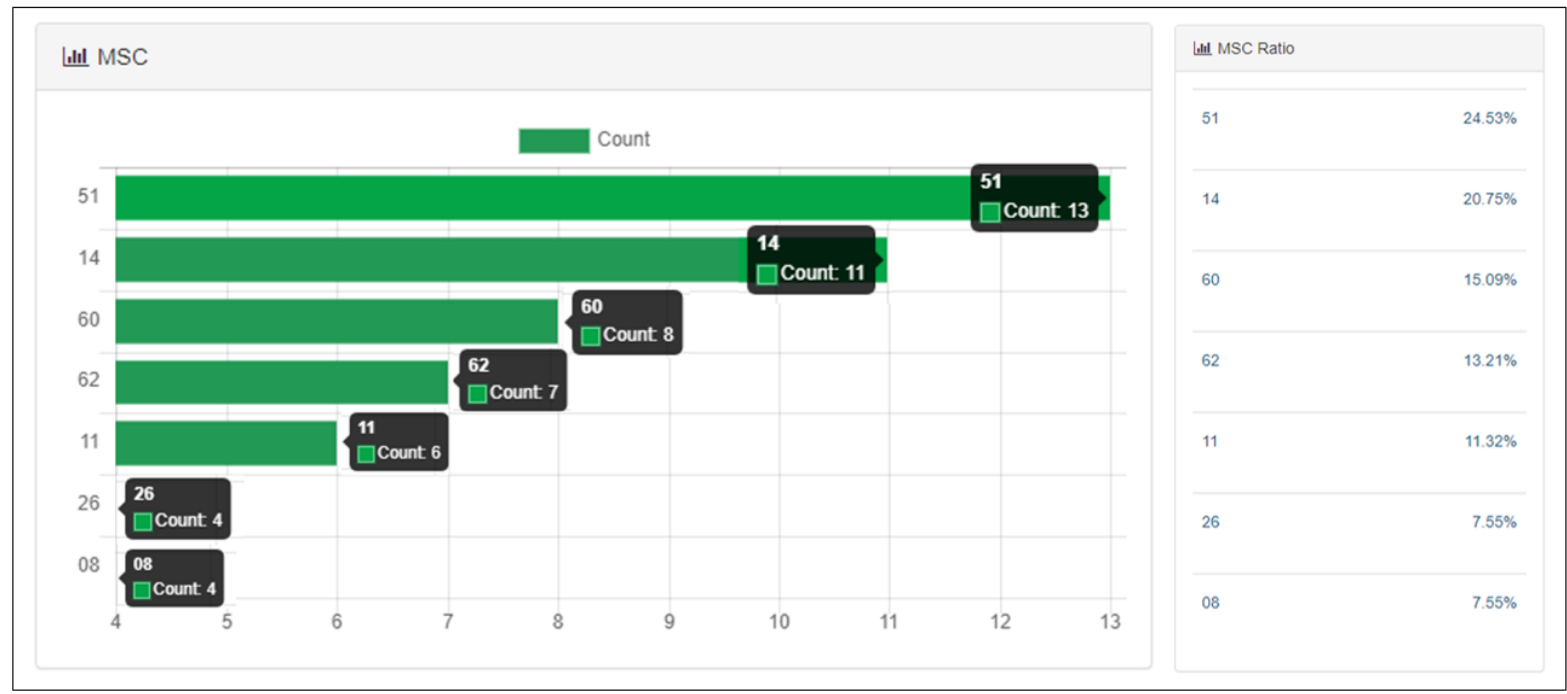

Figure 6. Results of Curriculum Analysis and Mathematics Lesson Plan Mathematics Subject Classifications (MSC) for Class VIII of Junior High School

The results of the curriculum analysis and mathematics lesson plan will also group topics from each mathematical material. CRMS has as many as 62 mathematical topics. The highest topic from the results of curriculum analysis and mathematics learning plan for class VIII of junior high school is the topic of Geometry which is symbolized by the number 51 there are as many as $24.53 \%$ or as many as 13 meetings in a learning year. This means that the topic of Geometry is more dominant than other topics taught to students in class VIII of junior high school. The lowest topic is the General Algeraic System topic symbolized by the number 08 there are as many as $7.55 \%$ or as many as 4 meetings in a year of learning taught to students in class VIII of junior high school.

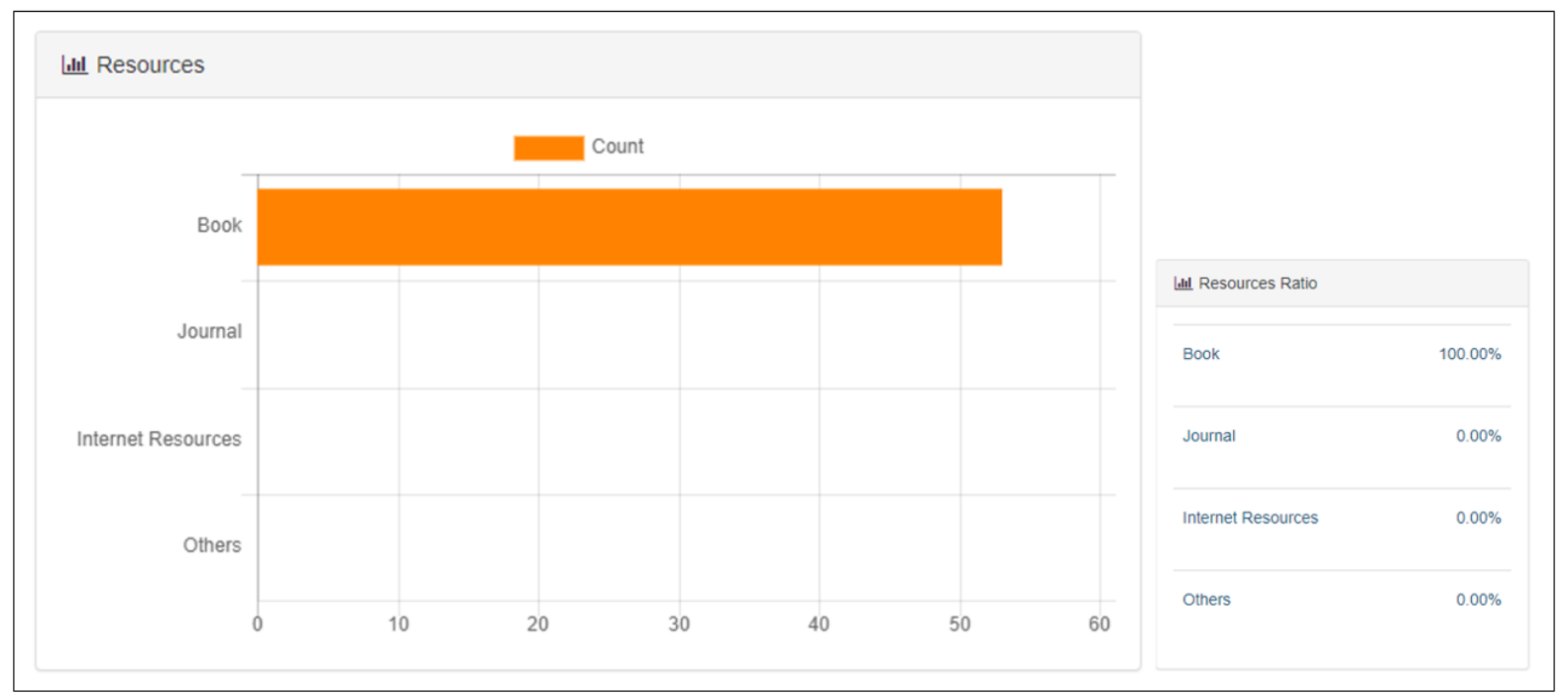

Figure 7. Results of Curriculum Analysis and Mathematics Lesson Plan Resources for Class VIII of Junior High School

In the learning program plan, there are learning resources of students. In this case the Resource provides information on the main learning resources of students in class VIII SMP where $100 \%$ comes from books. The teacher does not use other 
primary sources on any mathematics material taught such as journals, internet access, or anything else. Books are the main learning resources of students in the learning process taught by the school.

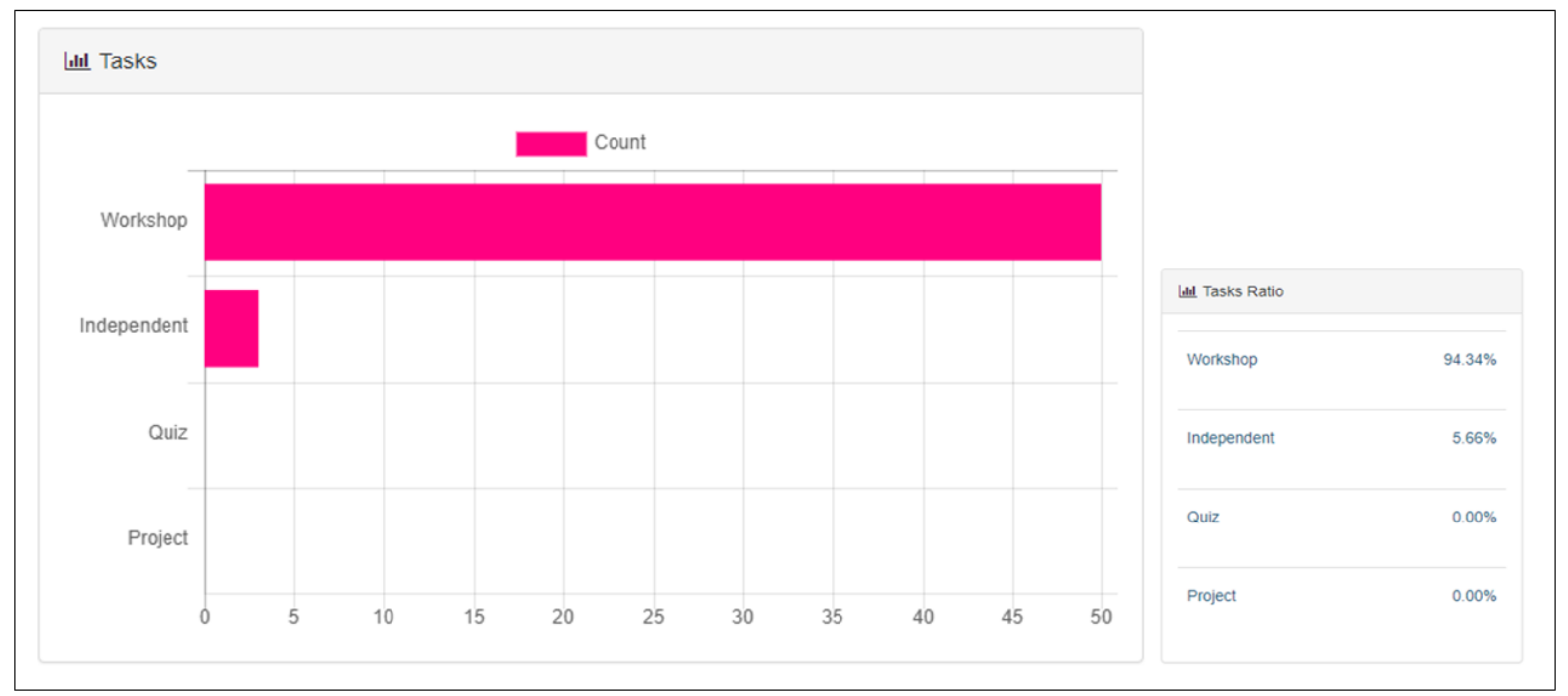

Figure 8. Results of Curriculum Analysis and Mathematics Lesson Plan Tasks for Class VIII of Junior High School

Tasks are mandatory in the teaching and learning process in order to train students in terms of responsibility, discipline, cooperation, independence, and various other kinds. Tasks given to students also have a role as a benchmark for the achievement of material that has been delivered by the teacher or educator in the classroom. In this CRMS system, one of the results presented is tasks. Tasks given by teachers or educators to students of class VIII of junior high school are more dominant tasks that are workshops that have a percentage of $94.34 \%$ and tasks that are independent with a percentage of 5.66\%.

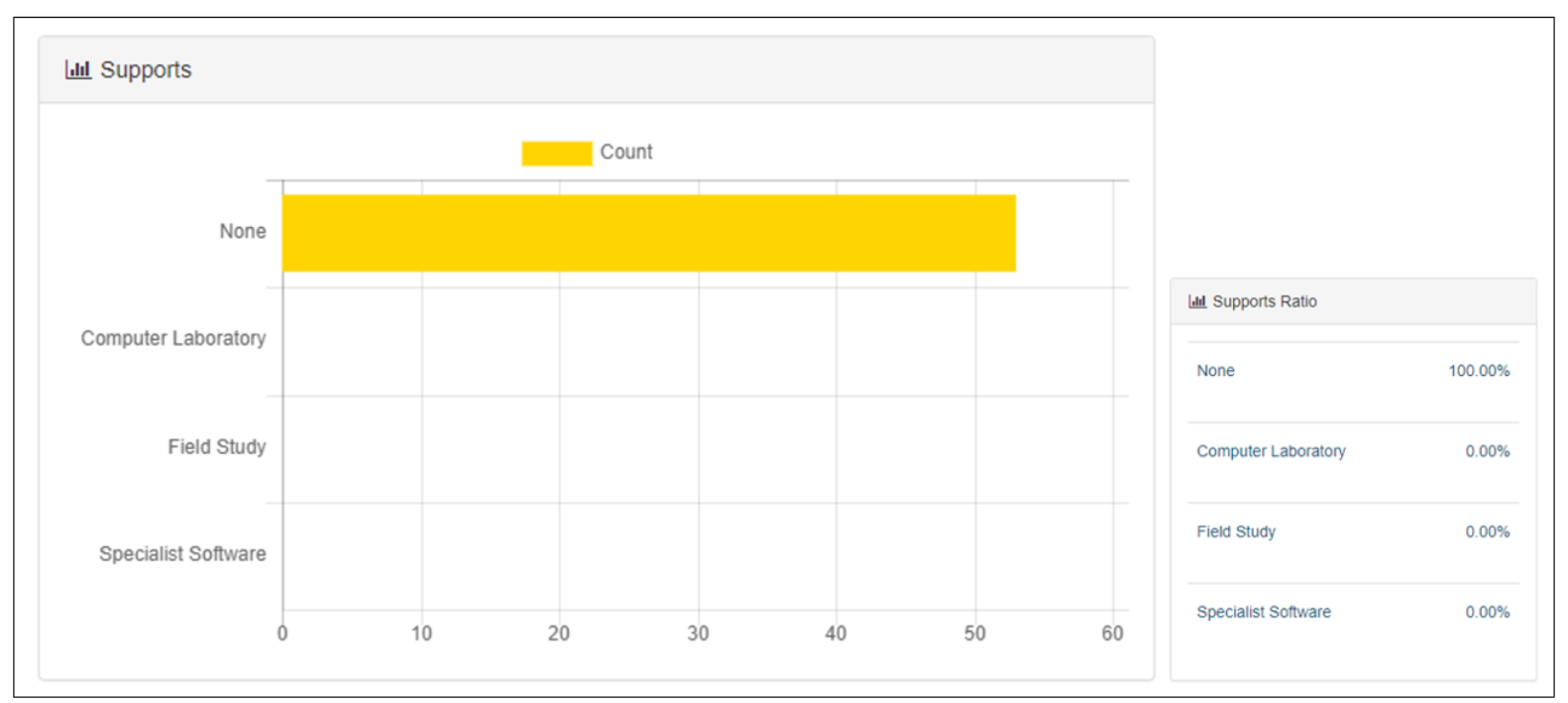

Figure 9. Results of Curriculum Analysis and Mathematics Lesson Plan Supports for Class VIII of Junior High School 
In the process of learning by teachers to students sometimes requires supports or support sources or learning media in a variety of material being taught. In the Class VIII implementation plan there are no teachers or educators who use support resources or learning media such as Computer Laboratory, Field Study, and Specialist Software in the learning process carried out in the classroom.

The results obtained by analyzing the curriculum and mathematics lesson plan of junior high school according to the mathematics teacher this system can help the teacher in the process of reviewing the mathematics lesson plan because by using the CRMS system the teacher can know the extent of the design of the mathematics lesson plan, the content or learning activities used, the material presented, and others. CRMS is considered an interesting and good analytical system so it must be published to help Indonesian mathematics teachers in the process of reviewing plans for implementing mathematics learning. The CRMS is also considered capable of being used as material for evaluating lesson plans, especially in evaluating material, assignments given by teachers to students, and others. Mathematics teachers hope that CRMS analysis system can be developed to be better and more complete so that teachers no longer take a long time in the process of reviewing mathematics lesson plans.

\section{CONCLUSION}

Based on the results of research and discussion it can be concluded that the use of CRMS is easy for mathematics teachers so that it can help mathematics teachers in analyzing curriculum and mathematics lesson plans. The CRMS also needs to be refined so that later the CRMS can be published to Indonesian mathematics teachers to facilitate the process of analyzing the mathematics curriculum at junior high schools.

\section{ACKNOWLEDGMENTS}

Researchers on the development of the Curriculum Review Mapping System (CRMS) Fathurrohman, Porter, Worthy, Abdullah, Supriyanto, Pamungkas., and Curriculum Review Mapping System (CRMS) funded by Research Grant Number: B/03/ UN43.9/PT.00.03/2020

\section{REFERENCES}

Alrajeh, T. S., \& Shindel, B. W. (2020). Student engagement and math teachers support. International Journal on Emerging Mathematics Education, 11(2), 167-180.

Fathurrohman, M., Porter, A., Worthy, A., Abdullah, R., Supriyanto, S., \& Pamungkas, A. S. (2019). Mathematics Curriculum Review by Advancing the Use of Learning Design Map and Subjects Classification. International Journal on Emerging Mathematics Education, 3(1), 27.

Gunawan, I. (2015). Metode Penelitian Kualitatif Teori dan Praktik (Suryani (ed.); Ketiga). Jakarta: PT Bumi Aksara.

Haqiqi, A. K. (2019). Telaah Implementasi Kurikulum 2013: Tinjauan Pada Rencana Pelaksanaan Pembelajaran ( RPP ) Mata Pelajaran Ilmu Pengetahuan Alam. Journal of Natural Science and Integration, 2(1), 12-18.

Johar, R., Yusniarti, S., \& Saminan. (2018). The Analysis Of Proportional Reasoning Problem In The Indonesian Mathematics Textbook For The Junior High 
School. International Journal on Emerging Mathematics Education, 9(1), 55-68. Kristiyani, C. (2019). Current School Curriculum Issues: A Case Of Student-Teacher Preparation In Higher Education. International Journal of Indonesian Education and Teaching, 3(2), 215-226.

Purwanto, N. (2014). Ilmu Pendidikan Teoritis dan Praktis. Bandung: Remaja Rosdakarya.

Ramda, A. H. (2017). Analisis Kesesuaian Materi pada Buku Teks Matematika Kelas VII dengan Kurikulum 2013. Jurnal Pendidikan Matematika, 12(1), 12-22.

Revina, S., \& Leung, F. K. . (2018). Educational Borrowing and Mathematics Curriculum: Realistic Mathematics Education in the Dutch and Indonesian Primary Curriculum. International Journal on Emerging Mathematics Education, 2(1), 1-16.

Rizkianto, I., \& Santosa, R. (2017). Analisis Buku Matematika Siswa Smp Kurikulum 2013. Jurnal Mosharafa, 6(2), 229-236.

Sudaryono. (2017). Metodologi Penelitian (Pertama). Jakarta: Raja Grafindo Persada.

Sugiyono. (2017). Penelitian Kualitatif, Kuantitatif, dan R\&D. Bandung: Alfabeta.

Suprapto. (2013). Metodologi Penelitian Ilmu Pendidikan dan Ilmu-Ilmu Pengetahuan Sosial (Pertama). Yogyakarta: Center for Academic Publishing Service (CAPS).

Wati, S., \& Jailani, J. (2016). Kesiapan Guru Matematika SMP di Kabupaten Purworejo dalam Implementasi Kurikulum 2013. Jurnal Pendidikan Matematika, 11(1), 77-90. 